\title{
Investment attractiveness of Ukrainian regions: rating assessment and marketing promotion
}

\author{
Ganna Kharlamova \\ Taras Shevchenko National University of Kyiv \\ Ukraine \\ akharlamova@ukr.net
}

\begin{abstract}
The paper reflects on the phenomenon of investment attractiveness and its assessment. Investment opportunities and potential of regions of Ukraine are analyzed. Regions are ranked according to their level of investment potential and the degree of investment risks, as well as an experience of previous investment activity in the region. Ranked groups of regions are considered for further marketing approach to be implemented with the aim to propose investment strategies for every particular region/group of regions to attract maximum efficient volume of investing. A comparative analysis of regional investment opportunities in the efficiency profile is held, regions-leaders are highlighted. The novelty of this paper mostly is about the proposed so-called territorial investment marketing, based on the results of a comprehensive monitoring of the regional investment climate of Ukraine. The research is focused on potential investors, governors, investment advisers and analytics.
\end{abstract}

Keywords: investment attractiveness, regions of Ukraine, rating assessment, marketing approach

JEL Classification: R11, C82, F21

\section{INTRODUCTION}

Investment topic - one of the most hackneyed in the information space - draws the mouth to everyone mainly due to the absence of any meaningful results in this field. For a long time officials declare hundreds of billions investments in need for the qualitative upgrading and modernization of sectors of the economy. In reality, attracted investments to the country are at least twice less productive. And according to the latest events on both the external and the domestic arena, it is not possible to count on the qualitative improvement of the situation in the near future. Taking in account that one of the main investors in Ukrainian economy (Russia) (about 7,5\% of total inwards, forth main investor) cannot be considered as such in the future, Ukraine is more challenged to find approach to "advertise" its regions and territories for EU and other foreign potential investors with the maximum efficiency. Nowadays Ukraine is in top news, so it can be one of the most efficient motor to attract foreign direct investments (FDI) and other investment resources. 


\section{RESEARCH METHODOLOGY}

Region level is chosen for consideration basing on the fact that there is quite sound provement (Bandurka et.al., 2004; Kharlamova, 2013; Nosova, 2001; Rogach, 2005) that while making decisions about investing the foreign business community takes into account regional factors. Same is confirmed by our mathematically grounded study of the effect of regional factors on FDI inwards (Kharlamova, 2007). So the research goal is to test the practical possibility to use results of rating assessment of investment attractiveness of regions (mostly based on the authorial approach (Kharlamova, 2013)) for their marketing promotion to potential investors (case of Ukraine). The research goal is stated alongside with research tasks:

- to use authorial method for investment attractiveness assessment on the regional level;

- to use rating assessment results for marketing analyses of regional investment climate of Ukraine;

- to propose marketing promotion strategy for Ukrainian regions under existing realities.

Restrictions of the research can be seen in the dynamic character of the investment climate that is changing from year to year; is flexible to the external factors and the situation. Thus, annual results should be calibrated with new challenges and adopted to new reality. But the mainstream approach proposed in the research hoped to remain. Major sources of data: State Statistics Service of Ukraine on the base of 2012-2013 statistical data stock. The novelty of this paper mostly is about the proposed so-called territorial investment marketing, based on the results of a comprehensive monitoring of the regional investment climate of Ukraine.

First of all, we revise broadly used approach to consider investors as highly motivated consumers of potential objects for investing. We go differently: if to consider potential investors as those that "provide (produce) specific services", while investment objects (in our study, regions) - as "consumers of these services", then a characteristic feature of regional investment marketing is that the target groups for searching and organization of optimal performance are not "customers" of services (in this case, the investment), but their "producers", i.e. private or legal persons who potentially may and wish to make investments. In this respect, the effectiveness of the investment marketing is dependent on both participants of this process. One of the major classical principles of advertising (Harvey McKay's moral code) appears to be relevant here: "The worm should be attractive for a fish, but not for a fisher." In the practice of classical marketing there are used various analytical approaches to strategic analysis based on factors considered as the most important and characteristic. Based on the basic approaches (Ansoff, 1989; Kotler, 1995; Kanischenko, 2004; Kovaliov et.al, 2000), we consider as an appropriate to choose for our further analysis the following:

\section{Boston Consulting Group Matrix (BCG Matrix):}

identifies 4 types of so-called strategic business units and determines the position and dynamics of various «products» on the market, depending on the intensity of its activity and life cycle;

\section{General Electric Multifactor Matrix (DPM) \\ ("McKinsey" research):}

shows (,traffic light principle”) relative importance of individual ,projects”, where the position of ,products" are widely divergent.

2 main variables: 1) the attractiveness of the market, which is characterized by the possibility of a ,subject" for business activity at it (low, medium, high), 2) the strategic position of the ,subject” (competitiveness), activity or business force (poor, average, good).

The degree of attractiveness of the investment climate in the region is determined by the combined influence of objective and subjective factors of investment. Objective opportunities in the region to attract FDI are the investment potential of the region, and objective obstacles that impede the implementation of such opportunities - a variety of regional investment risks, which existence determines the probability 
of incomplete implementation of the investment potential of the region. Our proposed method takes into account both objective and subjective components of investment: it is flexible, reasonable, and adequate to the reality (Kharlamova, 2013).

\section{RATING ASSESSMENT}

Ranking of investment attractiveness of regions of Ukraine is held by use of a statistical modelling technique proposed by (Kharlamova, 2007). The logic scheme is following:

1) Selection of statistics. Source of data is the official statistical reports (State Statistics Service of Ukraine, National Bank of Ukraine, Ministries of Ukraine). We took into account majority of statistical indicators that are available at the regional level in this data source. Regional investment attractiveness ranks and assessments should not depend on the amount of population and the size of regional areas. So every partial (mostly cost) values are included in the analysis only as relative values - rates, shares, per capita income, etc. In order to extract the influence of the size of a region and the amount of population living on its territory, we use the E. Engel indicator (ENG) (Soshnikova et.al., 1999):

$$
\mathrm{ENG}=\sqrt{T \cdot H}
$$

where $\mathrm{T}$ - territory, thous. $\mathrm{km}^{2}, \mathrm{H}$ - population of the region, thous.

2) Standardization of indicators.

3) Correlation analysis. We estimate the strength of the relationship between the amount of FDI attracted into regions (indicator: accumulated FDI in the region, gross/per capita, USA dollars) and each index component that determine investment potential (IP) and investment risks (IR) by means of the method of correlation analysis (calculating the linear correlation coefficient $(\rho)$ ). Note that accept to mentioned indicators of FDI inwards, other indicators of investment activity component (IA) are not taken into the correlation analysis because it is very clear that we obtain a tight multicorrelation. Correlation matrixes let us to consider for further analyses only main most influential factors/ indicators (multicorrelation is excluded):

\section{Production capital Factor (PC):}

- growth in agricultural output, $\%$ to prev. year;

- the region's exports, the share in total exports, \%;

- the region's imports, the share in total imports, \%;

- the share of companies that increased the volume of industrial production, in their total number in the region, \%;

- index of industrial production (industrial products), \% to prev. year;

- volume of investment products, a percentage of the volume of industrial products sales, $\%$.

Innovative capacity (innovation environment) Factor (InP):

- the share of innovative enterprises in the total number of industrial enterprises, $\%$;

- number of scientific organizations, a percentage of total number of enterprises in the country, \%;

- the amount of R\&D performed by organizations (enterprises), \% of the total in the country.

Institutional Potential (institutional capacity) Factor (InstP):

- the number of operating banks per 1,000 population;

- number of USREOU subjects per 1,000 population; 
- number of USREOU objects in private ownership, \% of the total output of enterprises with same type of ownership in the country;

- number of foreign companies in USREOU, \% of the total number of such enterprises in the country;

- number of small businesses per 10000 population.

Infrastructure potential (capacity) Factor (InfrF):

- value of the fixed assets implemented, hrv. per capita;

- consumption of gasoline, per the unit of area and per capita in the region, in terms of E. Engel;

- density of motorways per $100 \mathrm{~km}^{2}$;

- number of major home phone stations, per 100 households;

- commissioning of residential homes, $\mathrm{m}^{2}$ total area per 1 inhabitant in the region..

Human Capital Factor (HC):

- employed population in all areas of economic activity, $15-70$ years, $\%$ of total population of the corresponding age;

- number of persons enrolled in universities of III-IV accreditation levels, $\%$ of total number of persons who are in training at higher education institutions in the country.

Nature-geographic Potential Factor (NGP):

- productivity of major crops, cereals, c per 1 ha;

- number of foreign countries with common boarders with the region.

Consumption Potential Factor (CP):

- retail turnover of enterprises engaged in retail trade and restaurant business, hrv. per capita;

- wholesale turnover, hrv. per capita;

- average wage per 1 permanent employee, hrv.;

- volume of services sold to the population, hrv. per capita at current prices.

Financial Potential Factor (FP):

- number of enterprises that have received operative income, $\%$ of the total in the region;

- volume of deposits in national currency, hrv. per capita in the region;

- volume of loans granted by commercial banks to entrepreneurs, \% of total amount of such loans.

Social Risks Factor (SR):

- the average number of unemployed persons registered at the employment agency, \% of economically active population of working age.

Economic Risks Factor (ER):

- number of enterprises experienced negative incomes from operative activities, $\%$ of total enterprises in the region;

- the part of companies that have reduced production output, \% of their total number in the region.

Ecological Risks Factor (EcoR):

- natural gas consumption per unit of area and per capita in the region, in terms of E.Engel;

- number of reported fires and burnings, $\%$ of total over the country.

Criminal Risks Factor (CR):

- number of reported crimes, thous.

Note, that while the assessment of investment attractiveness of regions of Ukraine we traced an interesting nuance: leveling of the influence of the "cheap labor" factor and even demographic factors at all (human capital indexes). This trend was observed in our annual monitoring of investment capital conducted since 2000 (Kharlamova, 2003; 2006; 2013). Thus, the presence of the cheap labor factor at the Ukrainian labor market should not be overestimated. As well, according to the statistics same can be proved: in terms of sci- 
entists and engineers per capita, Ukraine is one of the leading countries (in the first quarter of the list), but only $8 \%$ of the country's exports accounted for production of high-tech sector.

The question arises: "Cheap labor in Ukraine: Myth or Reality “. Availability of a cheap labor in Ukraine foreign investors do not find as a significant motive for investment, as indicated by our study and representative surveys (Soldatenko et.al., 2005). This should be considered in contrasts to the economists who often emphasize that the attractiveness of Ukraine is in terms of cheap labor. This difference in views indicates the necessity to distinguish between nominal salaries and total labor costs. The latter counts productivity, costs of complying with the requirements of the governing bodies and other factors. Due to the lack of capital, of proper training and poor management the labor productivity in Ukraine is often so low that the total costs of labor are greater than in other Eastern European countries. In the case of purchasing an ongoing concern a new owner cannot quickly dismiss or retrain a large number of workers, so the productivity for a long time will remain low. Local government, which is trying to maintain the level of employment, usually imposes restrictions to reduce the number of employees, thereby significantly increasing the overall cost of labor. In addition, foreign investors are often required to maintain the social infrastructure of large enterprises. These obstacles eventually nullify all the benefits of low-wage labor in Ukraine.

4) Cluster analyses. We perform clustering of regions for each indicator by k-means technique (according to 6 clusters) automatically in Statistica software, Cluster Analysis option (Multivariate Exploratory Techniques Menu). According to the mean values of each cluster we distribute regions at the level of each latter indicator. We state that cluster 1 is the highest level, 2 - high, 3 - average, 4 - satisfactory (moderate) level, 5 - poor, 6 - the lowest level of investment attractiveness performance of an indicator. Remark that the investment risks indicators (IR) are estimated with account of the negative impact of these parameters on the investment attractiveness of the region. Thus, the 1 st cluster includes regions with the lowest riskiness, and the 6th - the highest.

5) Integral assessment. Basing the numbers of clusters in which the region has been classified by the value of each indicator, we determine cumulative assessment (score from 1 to 6) for each region at the level of each factor (fig. 1-3) and provide a certain place (from the 1st to 26th) for each region among others (here we used authorial method (Kharlamova, 2013). Figures 1-3 are already the first marketing tool to promote regions as a first-hand (de visu) demonstration of positions of regions among each other. Radii ("rays") are used as the axes. The countdown goes from the center of the diagram, which consists of concentric circles (rings). The center of the circle corresponds to the estimation - " 1 " and the last concentric circle from the center - the estimation - " 6 ", respectively. All radii (beams) are gathering in the center. The number of radii corresponds to the number of regions (26 radii). At each radius (ray) certain point markers are shown that correspond to the appropriate evaluation according to a particular factor for the region. Markers of the same color are connected by lines for clarity of the overall picture according to a particular factor. 




Figure 1. Spider chart of regions of Ukraine by IP factors

Source: author's calculations

Fig. 1 demonstrates the ability for a potential investor to see immediately that, for example, the Kyiv city occupies " 1 " assessment position according to mostly all factors of the investment potential component (relevant markers are in the center), but the "2" assessment for the production capacity (PC) factor and "6 “- for nature-geographical potential (NGP).

Fig. 2 provides potential investors with the full picture of the investment risks. And, for example, Kyiv occupies "1" assessment position according to its social risk (SR) ("least risky"), "2" - to its economic risks (ER), but " 4 " - according to its criminal risks (CR) and "6" - for its environmental risks (EcoR).

Fig. 3 pictures for potential investors the absolute advantage of Kyiv - "1" assessment position according to all factors of the investment activity component.

Then for each region of Ukraine, we sum up the integral assessment of every component of investment attractiveness: IP, IA, IR (based on the results presented in Fig. 1-3), and assign a particular place in the ranking for every region (Table 1). Table 1 is colored according to the stage of clustering, and identifies six levels of evaluation:

1 - red zone - the highest level of investment attractiveness;

2 - orange zone - high level;

3 - yellow zone - average level;

4 - green zone - moderate (satisfactory) level;

5 - blue zone - low level;

6 - gray zone - the lowest level. 


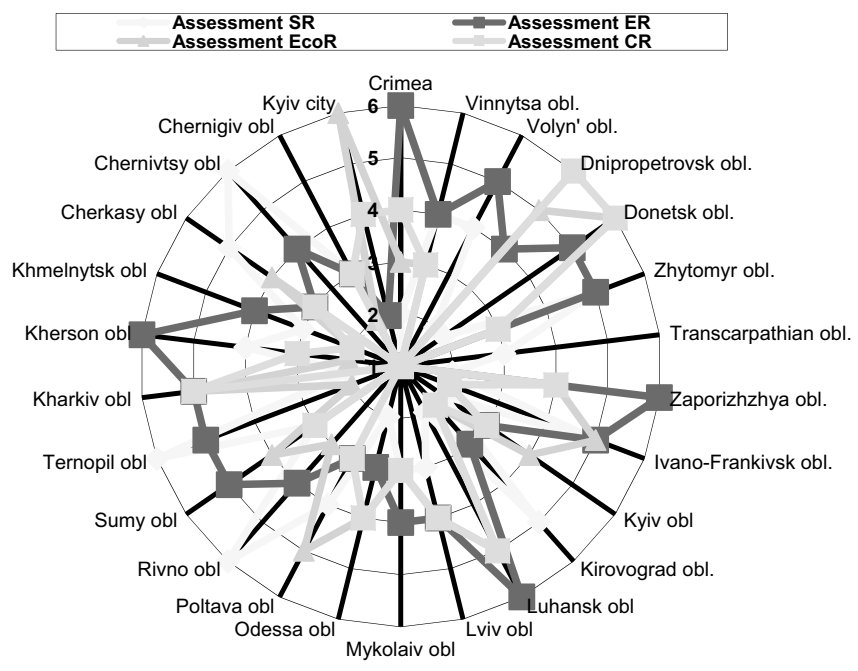

Figure 2. Spider chart of regions of Ukraine by IR factors

Source: author's calculations

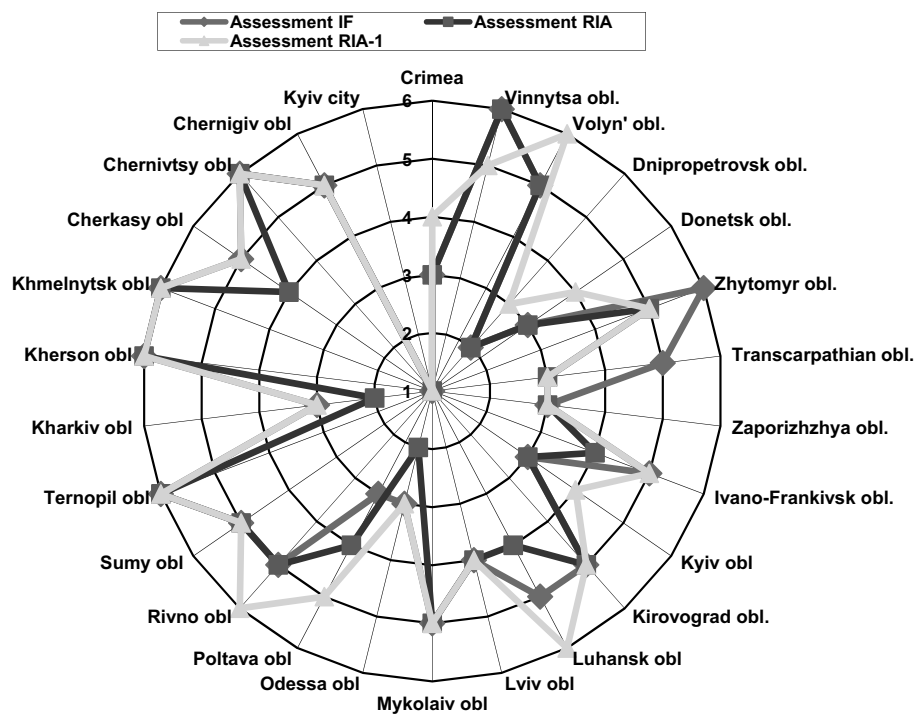

Figure 3. Spider chart of regions of Ukraine by IA factors

Source: author's calculations

According to Table 1 we can result that Kyiv implicitly leads, as according to the investment potential and to the investment activity, although it experienced relatively significant investment risks. The lowest investment risk is in Transcarpathian region; however it has the low investment capacity. 
Rating characteristics of investment attractiveness of regions of Ukraine

\begin{tabular}{|c|c|c|c|c|c|c|}
\hline \multirow{3}{*}{$\begin{array}{l}\text { Regions of Ukraine } \\
\text { (oblasts) }\end{array}$} & \multicolumn{6}{|c|}{ Integral assessment } \\
\hline & \multicolumn{2}{|c|}{ Investment potential (IP) } & \multicolumn{2}{|c|}{$\begin{array}{l}\text { Investment risks } \\
\text { (IR) }\end{array}$} & \multicolumn{2}{|c|}{$\begin{array}{l}\text { Investment activity } \\
\text { (IA) }\end{array}$} \\
\hline & Assessment & Place & Assessment & Place & Assessment & Place \\
\hline Cherkasy obl & 5 & 15 & 4 & $16-19$ & 5 & $12-13$ \\
\hline Chernigiv obl & 6 & $20-21$ & 3 & 2 & 5 & $14-17$ \\
\hline Chernivtsy obl & 5 & 19 & 4 & $10-11$ & 6 & $23-26$ \\
\hline Crimea & 4 & 10 & 4 & $14-15$ & 3 & $6-9$ \\
\hline Dnipropetrovsk obl. & 3 & 2 & 5 & 24 & 2 & 2 \\
\hline Donetsk obl. & 3 & 3 & 6 & 26 & 3 & $6-9$ \\
\hline Ivano-Frankivsk obl. & 5 & 18 & 5 & $21-22$ & 5 & $12-13$ \\
\hline Kharkiv obl & 3 & 4 & 5 & $21-22$ & 3 & $3-4$ \\
\hline Kherson obl & 6 & $20-21$ & 4 & $14-15$ & 6 & $23-26$ \\
\hline Khmelnytsk obl & 6 & $22-23$ & 3 & $3-4$ & 6 & $23-26$ \\
\hline Kirovograd obl. & 6 & $24-26$ & 3 & $3-4$ & 5 & $14-17$ \\
\hline Kyiv city & 1 & 1 & 4 & 12 & 1 & 1 \\
\hline Kyiv obl & 4 & 9 & 3 & 5 & 3 & $6-9$ \\
\hline Luhansk obl & 6 & $24-26$ & 5 & 25 & 5 & 18 \\
\hline Lviv obl & 4 & 8 & 4 & 9 & 4 & 10 \\
\hline Mykolaiv obl & 5 & 11 & 3 & 6 & 5 & $14-17$ \\
\hline Odessa obl & 4 & 6 & 4 & 7 & 3 & $3-4$ \\
\hline Poltava obl & 4 & 7 & 4 & $16-19$ & 4 & 11 \\
\hline Rivno obl & 5 & 16 & 4 & 13 & 5 & 19-21 \\
\hline Sumy obl & 5 & 13 & 4 & $16-19$ & 5 & $14-17$ \\
\hline Ternopil obl & 6 & $24-26$ & 5 & 23 & 6 & $23-26$ \\
\hline Transcarpathian obl. & 5 & 17 & 1 & 1 & 3 & $6-9$ \\
\hline Vinnytsa obl. & 5 & 14 & 4 & 8 & 6 & 22 \\
\hline Volyn' obl. & 5 & 12 & 4 & $10-11$ & 5 & $19-21$ \\
\hline Zaporizhzhya obl. & 3 & 5 & 4 & $16-19$ & 3 & 5 \\
\hline Zhytomyr obl. & 6 & $22-23$ & 5 & 20 & 5 & $19-21$ \\
\hline
\end{tabular}

Source: author's calculations

Marketing approach. Next step is to use received ranking assessments of regions according to its investment attractiveness for the marketing presentation and promotion of Ukrainian territories. Rather interesting and demonstrative for potential investor is a table of comparability "potential -risks". Based on the values of integrated assessments IP and IR (Table 1), we construct a 6x6 "IP-IR" matrix in which cells we note the number of regions that fall to certain areas at the crossroads of the column (IR) and the raw (IR) (Table 2). 
Table 2

"IP-IR" matrix

\begin{tabular}{|c|c|c|c|c|c|c|c|}
\hline $\begin{array}{c}\text { IR } \\
\text { IP }\end{array}$ & $\begin{array}{c}1 \\
\text { minimal }\end{array}$ & $\begin{array}{c}2 \\
\text { modest }\end{array}$ & $\begin{array}{c}3 \\
\text { moderate }\end{array}$ & $\begin{array}{c}4 \\
\text { average }\end{array}$ & $\begin{array}{c}5 \\
\text { high }\end{array}$ & $\begin{array}{c}6 \\
\text { maximal }\end{array}$ & Total \\
\hline $\begin{array}{c}2 \\
\text { High }\end{array}$ & & & & 1 & & & 0 \\
\hline $\begin{array}{c}3 \\
\text { Average }\end{array}$ & & & & 1 & 2 & 1 & 4 \\
\hline $\begin{array}{c}4 \\
\text { Moderate }\end{array}$ & & & 1 & 4 & & & 5 \\
\hline $\begin{array}{c}5 \\
\text { Low }\end{array}$ & 1 & & 1 & 6 & 1 & & 9 \\
\hline $\begin{array}{c}6 \\
\text { The lowest }\end{array}$ & & & 3 & 1 & 3 & & 7 \\
\hline \begin{tabular}{c} 
Total \\
\hline
\end{tabular} & 1 & 0 & 5 & 13 & 6 & & 1 \\
\hline
\end{tabular}

Source: author's calculations

It is shown that if the high investment potential (IP) is accompanied by a high risk (IR), then the colored cells would be filled in. However, table 2 demonstrates that there is no unambiguous connection. There are only 2 regions in colored cells. Most regions - 13 - represent average IR, and 6 of them are marked with low IP (the most filled cell of the matrix). This indicates a lack of balance in the investment climate of Ukraine (at the regional level).

Similarly, we check comparability «investment potential - investment activity» by a matrix of «IP- IA» (Table 3)

Table 3

Matrix „IP-IA”

\begin{tabular}{|c|c|c|c|c|c|c|c|}
\hline $\begin{array}{l}\text { IA } \\
\text { IP }\end{array}$ & $\begin{array}{c}1 \\
\text { The highest }\end{array}$ & $\begin{array}{c}2 \\
\text { High }\end{array}$ & $\begin{array}{c}3 \\
\text { Average }\end{array}$ & $\begin{array}{c}4 \\
\text { Moderate }\end{array}$ & $\begin{array}{c}5 \\
\text { Low }\end{array}$ & $\begin{array}{c}6 \\
\text { The lowest }\end{array}$ & Total \\
\hline $\begin{array}{c}1 \\
\text { The highest }\end{array}$ & 1 & & & & & & 1 \\
\hline $\begin{array}{c}2 \\
\text { High }\end{array}$ & & & & & & & 0 \\
\hline $\begin{array}{c}3 \\
\text { Average }\end{array}$ & & 1 & 3 & & & & 4 \\
\hline $\begin{array}{c}4 \\
\text { Moderate }\end{array}$ & & & 3 & 2 & & & 5 \\
\hline $\begin{array}{c}5 \\
\text { Low }\end{array}$ & & & 1 & & 6 & 2 & 9 \\
\hline $\begin{array}{c}6 \\
\text { The lowest }\end{array}$ & & & & & 4 & 3 & 7 \\
\hline Total & 1 & 1 & 7 & 2 & 10 & 5 & 26 \\
\hline
\end{tabular}

Source: author's calculations 
Unlike matrix "IP-IR" the distribution of regions in terms of investment activity sufficiently meets their distribution in terms of investment potential. This is evidenced by filling of cells along the main diagonal (Table 3).

Further, based on Table 1, using our authorial method (Kharlamova, 2013) we calculate regional assessment for the final integrated assessment of investment attractiveness (Table 4).

Table 4

Regional integrated assessment of investment attractiveness

\begin{tabular}{|c|c|c|}
\hline Regions of Ukraine (oblasts) & $\begin{array}{l}\text { Integrated assessment of } \\
\text { investment attractiveness }\end{array}$ & Place in the rank \\
\hline Cherkasy obl & 5 & $13-16$ \\
\hline Chernigiv obl & 5 & $18-19$ \\
\hline Chernivtsy obl & 5 & $20-21$ \\
\hline Crimea & 4 & $8-9$ \\
\hline Dnipropetrovsk obl. & 3 & 3 \\
\hline Donetsk obl. & 3 & $4-7$ \\
\hline Ivano-Frankivsk obl. & 5 & 17 \\
\hline Kharkiv obl & 3 & $4-7$ \\
\hline Kherson obl & 6 & 25 \\
\hline Khmelnytsk obl & 6 & 24 \\
\hline Kirovograd obl. & 5 & 18-19 \\
\hline Kyiv city & 1 & 1 \\
\hline Kyiv obl & 3 & $4-7$ \\
\hline Luhansk obl & 5 & $22-23$ \\
\hline Lviv obl & 4 & $10-11$ \\
\hline Mykolaiv obl & 5 & 12 \\
\hline Odessa obl & 4 & $8-9$ \\
\hline Poltava obl & 4 & $10-11$ \\
\hline Rivno obl & 5 & $13-16$ \\
\hline Sumy obl & 5 & $13-16$ \\
\hline Ternopil obl & 6 & 26 \\
\hline Transcarpathian obl. & 3 & 2 \\
\hline Vinnytsa obl. & 5 & $20-21$ \\
\hline Volyn' obl. & 5 & $13-16$ \\
\hline Zaporizhzhya obl. & 3 & $4-7$ \\
\hline Zhytomyr obl. & 5 & $22-23$ \\
\hline
\end{tabular}

Source: author's calculations

Table 4, itself is a "guide" for potential investors for the investing solutions. Our achievement in comparison with existing methods is that we provide as a gross integrated assessment of investment attractiveness (overall rating), as well as an opportunity for a investor to compare "Potential - Activeness - Risks" assessments for their own conclusions. Thus we provide a potential investor with a "inner meaning" of a place of a region in the rating. As well, the distribution of regions by a comprehensive basis of investment attractiveness can be represented as in Table 5. 
Table 5

The distribution of the regions according to regional integrated assessment of investment attractiveness

\begin{tabular}{|c|c|c|c|}
\hline Zone title & Descriptive title of a zone & Regions & $\begin{array}{l}\text { Amount } \\
\text { of regions }\end{array}$ \\
\hline $\begin{array}{l}\text { Zone of the highest invest- } \\
\text { ment attractiveness }\end{array}$ & „Metropolis”, „leader” & Kyiv city & 1 \\
\hline $\begin{array}{l}\text { Zone of high investment } \\
\text { attractiveness }\end{array}$ & „Persecuting”, „Pretending” & $\begin{array}{c}\text { Transcarpathian obl., Dnipropetrovs'k } \\
\text { obl. }\end{array}$ & 2 \\
\hline $\begin{array}{l}\text { Zone of average investment } \\
\text { attractiveness }\end{array}$ & „Master file” & $\begin{array}{c}\text { Donetsk obl., Zaporizhzhya obl., Kyiv } \\
\text { obl, Kharkiv obl }\end{array}$ & 4 \\
\hline $\begin{array}{l}\text { Zone of satisfactory invest- } \\
\text { ment attractiveness }\end{array}$ & "Moderate" & $\begin{array}{c}\text { Crimea, Odessa obl., Lviv obl., Poltava } \\
\text { obl. }\end{array}$ & 4 \\
\hline \multirow[b]{2}{*}{$\begin{array}{l}\text { Zone of low investment at- } \\
\text { tractiveness }\end{array}$} & „Unattractive” but low risky & $\begin{array}{l}\text { Mykolaiv obl., Kirovograd obl., Cherni- } \\
\text { giv obl. }\end{array}$ & 3 \\
\hline & „Unattractive” & $\begin{array}{c}\text { Volyn' obl.., Rivno obl., Sumy obl., } \\
\text { Cherkasy obl., Ivano-Frankivsk obl., } \\
\text { Luhansk obl., Zhytomyr obl., Chernivtsi } \\
\text { obl., Vinnytsya obl. }\end{array}$ & 9 \\
\hline $\begin{array}{l}\text { Zone of the lowest invest- } \\
\text { ment attractiveness }\end{array}$ & „Outsider” & $\begin{array}{c}\text { Khmelnitska obl., Kerson obl., Ternopil } \\
\text { obl. }\end{array}$ & 3 \\
\hline \multicolumn{3}{|c|}{ Total } & 26 \\
\hline
\end{tabular}

Source: author's calculations.

Regions in the bottom of the ranking Table 5 (Zone of low investment attractiveness) are characterized by dense rating places, making possible "eye-popping" ups and downs. It is interesting to note that in recent years so-called "neighbor's cow" effect was often observed while changing positions by regions. That means, the growth is not due to improvements in certain areas, but because of deterioration in other regions. And allegations about "local growth points" are currently not reasonable at the regional level.

As to the top of the ranking Table 5, the situation is slightly different. Ukrainian "investment warming" in 2004 observed in statistics and confirmed by international rating agencies affected the investment climate in some regions, but now the Kyiv city again positions the leader role in substantial isolation from other regions of Ukraine and this will stay the same in next 3-5 years undoubtedly.

The distribution of regions according to the integral assessment of investment attractiveness (Table 5) results the conclusion that the greatest attractiveness belongs to industrialized regions.

A distinctive feature of the proposed approach is to examine the investment attractiveness of the region of Ukraine in a causal relation to investment activity in it. This approach allows us to solve the problem of quantitative criteria of efficiency of the implementation of the investment potential of the region (Table 6). 
Efficiency of the implementation (E) of the investment potential of the region ${ }^{1}$

\begin{tabular}{|c|c|c|c|}
\hline Regions of Ukraine (oblasts) & $\mathrm{IA}_{\mathrm{t+1}}$ & $\mathrm{IP}_{\mathrm{t}}$ & $\mathrm{E}=\mathrm{IA}_{\mathrm{t}+1} / \mathrm{IP}_{\mathrm{t}}$ \\
\hline Cherkasy obl & 6 & 5 & 1,2 \\
\hline Chernigiv obl & 6 & 6 & 1 \\
\hline Chernivtsy obl & 6 & 5 & 1,2 \\
\hline Crimea & 4 & 4 & 1 \\
\hline Dnipropetrovsk obl. & 2 & 3 & 0,7 \\
\hline Donetsk obl. & 3 & 3 & 1 \\
\hline Ivano-Frankivsk obl. & 6 & 5 & 1,2 \\
\hline Kharkiv obl & 4 & 3 & 1,3 \\
\hline Kherson obl & 6 & 6 & 1 \\
\hline Khmelnytsk obl & 6 & 6 & 1 \\
\hline Kirovograd obl. & 6 & 6 & 1 \\
\hline Kyiv city & 1 & 1 & 1 \\
\hline Kyiv obl & 3 & 4 & 0,75 \\
\hline Luhansk obl & 6 & 6 & 1 \\
\hline Lviv obl & 4 & 4 & 1 \\
\hline Mykolaiv obl & 6 & 5 & 1,2 \\
\hline Odessa obl & 3 & 4 & 0,75 \\
\hline Poltava obl & 5 & 4 & 1,25 \\
\hline Rivno obl & 6 & 5 & 1,2 \\
\hline Sumy obl & 6 & 5 & 1,2 \\
\hline Ternopil obl & 6 & 6 & 1 \\
\hline Transcarpathian obl. & 5 & 5 & 1 \\
\hline Vinnytsa obl. & 6 & 5 & 1,2 \\
\hline Volyn' obl. & 6 & 5 & 1,2 \\
\hline Zaporizhzhya obl. & 3 & 3 & 1 \\
\hline Zhytomyr obl. & 6 & 6 & 1 \\
\hline
\end{tabular}

Source: author's calculations

Since " 1 " is the best rating assessment and " 6 " - the lowest, than the value of $E \leq 1$ indicates a better use of the investment potential of the region by effectively neutralizing the negative impact of investment risks and creating organizational and economic means for more effective incentives for investors.

1 The assessment $\mathrm{IA}_{\mathrm{t}+1}$ is calculated by means of $\mathrm{k}$-mean cluster analysis $(\mathrm{k}=6)$ on the base of FDI inwards in the region for a period $t+1$. IP assessment is taken from the Table 1 . 


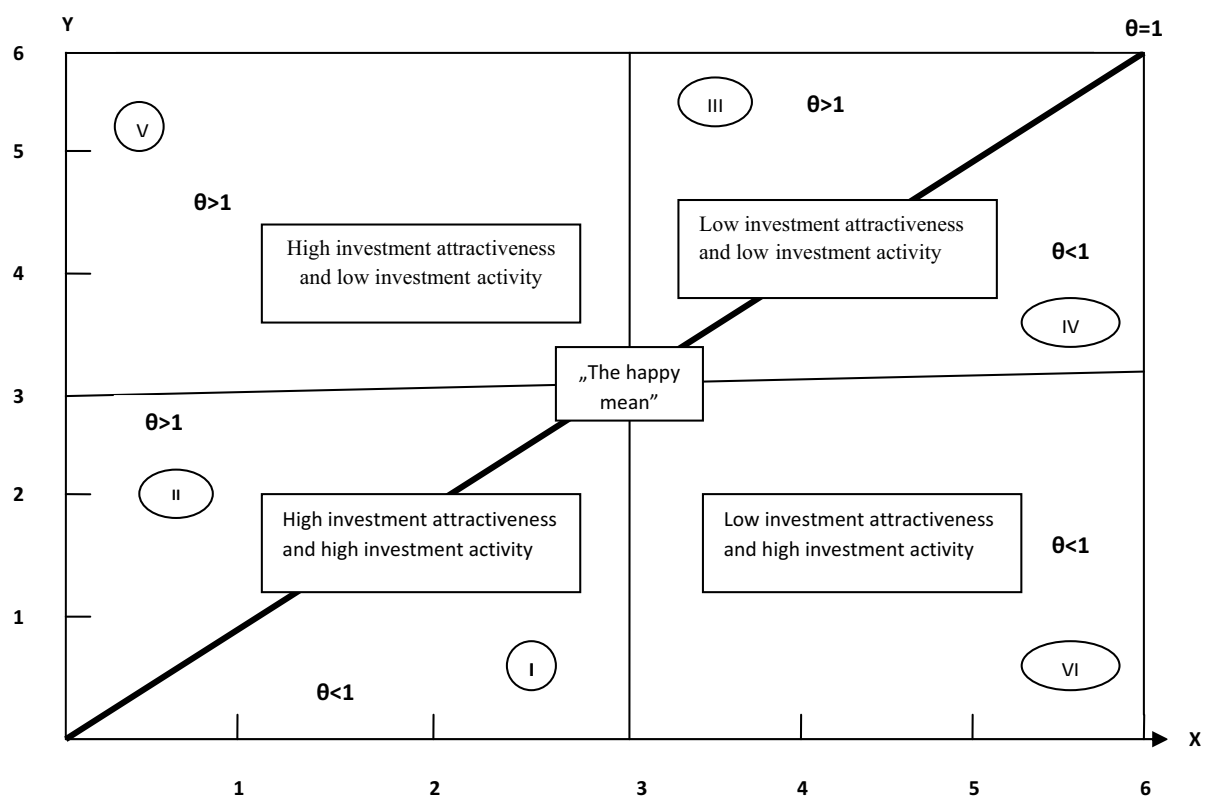

Figure 4. «System of axes» for the classification of regions of Ukraine according to their efficiency of the investment process

Source: author's calculations

For marketing usage of these results we construct an «axis of references» (Fig. 4). We consider the investment space of Ukraine in the two-dimensional coordinate system $(\mathrm{X}, \mathrm{Y})$. X-axis is the level of investment attractiveness (Table 4) and the vertical axis (Y) - investment activity (assessment IAt +1 , Table 6). Study of the location of regions at the graph relatively to these axes, as well as on the «line of efficiency», i.e. the line that corresponds to the full adequacy of investment attractiveness usage $(X i=\mathrm{Y} i, \theta i=1)$, allows to formulate the criterion for identification of regions of Ukraine to a particular classification group according to the efficiency of the investment process in it. Value $\theta$ is the degree of the investment attractiveness usage in the region: $\theta=\mathrm{Y} / \mathrm{X}$. Investment space of Ukraine we divide by 6 sectors (I-VI). Dividing lines are the «middle» axis and «line of efficiency.»

It is easy to see that the regions which fall within the sectors that are left to the vertical «middle» axis have high zone of attractiveness (sectors I, II, V), and the regions that fall into the sectors to the right of the vertical «middle» axis - conversely, zones of low investment attractiveness (sectors III, IV, VI). For sectors that are below the horizontal "middle» line, are characterized, respectively, with high investment activity (sectors I, II, VI), and sectors III, IV, V, located above this line contain regions with low investment activity. Regions that are within the sectors upstream the «line of efficiency» (sectors II, III, V), use their investment attractiveness not completely $(\theta>1)$, and require careful investment strategy design for more productive investment promotion. Regions that are trapped in the lower sectors from the "line of efficiency» (sectors I, IV, VI), fully use their investment attractiveness, even in excess of their objective features $(\theta<1)$. According to this logic «axis of references» regions are located as follows (Figure 5). 


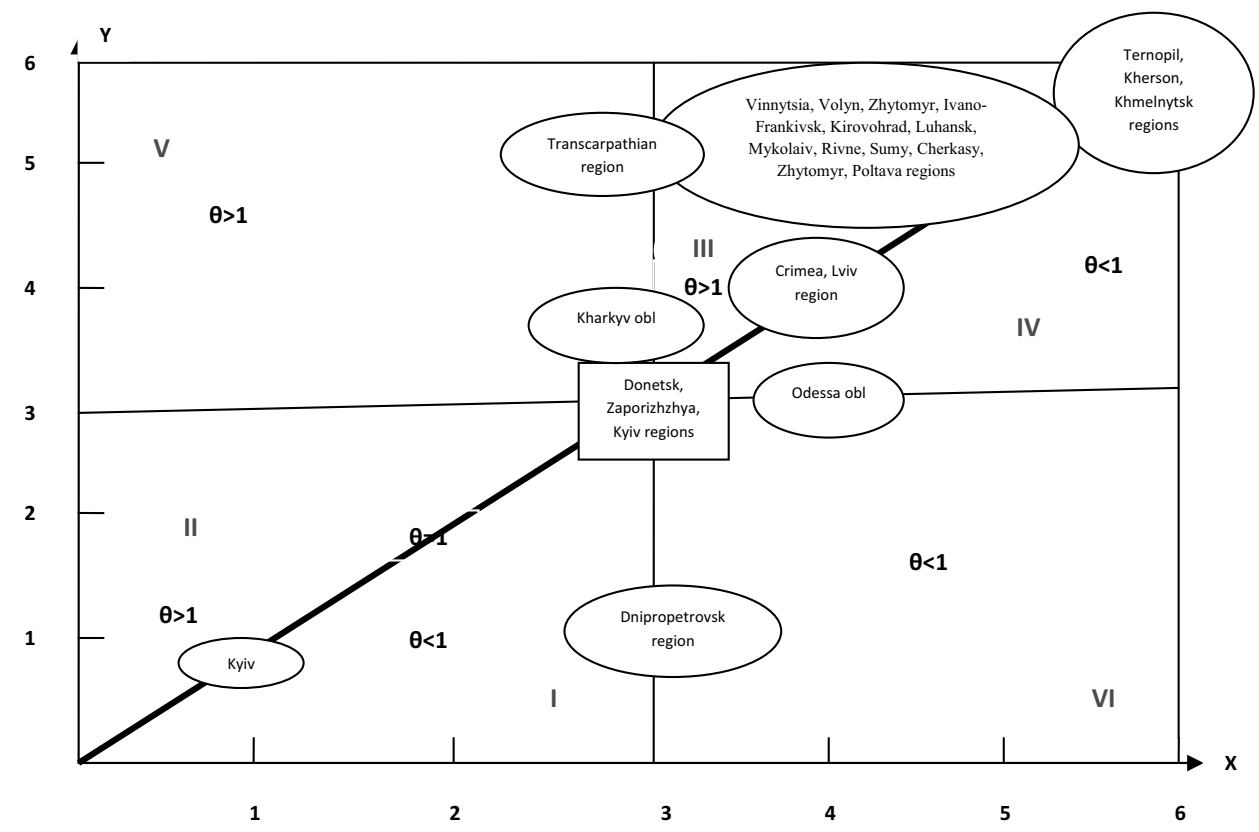

Figure 5. The classification of regions of Ukraine according to their efficiency of the investment process Source: author's calculations

To be sure in our results we calculate the Spearman rank correlation coefficient $(\eta)$ and the simple correlation coefficient $(\rho)$ :

- between $I A \mathrm{t}+1$ and $I P \mathrm{t}: \eta=0,996, \rho=0,90$;

- between $I A \mathrm{t}+1$ and investment attractiveness: $\eta=0,993, \rho=0,89$.

Spearman rank correlation coefficients $(\eta)$ confirm the high relevance of the results of the monitoring to the realities. The degree of tightness of correlation $(\rho)$ also points to the adequacy of the proposed monitoring. That is, our proposed method gives sufficient adequate assessments.

Evaluation of investment attractiveness and its components (Table 1) makes feasible to apply marketing positioning of regions of Ukraine, namely construct an analogue BCG matrix - Matrix "investment activity (IA) - Investment potential (IP)" (Table 7) and to propose to the respective blocks of matrix corresponding investment strategies. 
Matrix „IA-IP”

\begin{tabular}{|c|c|c|}
\hline & $\begin{array}{l}\text { High investment activity } \\
\text { (IA assessment }=\{1 ; 2 ; 3\})\end{array}$ & $\begin{array}{l}\text { Low investment activity } \\
\text { (IA assessment }=\{4 ; 5 ; 6\})\end{array}$ \\
\hline $\begin{array}{c}\text { High investment } \\
\text { potential } \\
(\text { IP assessment }= \\
\{1 ; 2 ; 3\})\end{array}$ & $\begin{array}{c}\text { „Stars"(leaders) } \\
\text { Kyiv city, Dnipropetrovs 'k, Donetsk., } \\
\text { Zaporizhzhya, Kharkiv regions. } \\
\text { (high investment potential meets strong } \\
\text { leading investment position) } \\
\text { Strategy - holding positions. }\end{array}$ & $\begin{array}{c}\text { „Applicants", } \\
\text { ("Question marks" } \\
\text { (unrealized potential) } \\
\text { No region according to the date of the monitoring } \\
\text { (undervalued investment potential) } \\
\text { Strategy - reinforcement. Intensification of mar- } \\
\text { keting to promote the region to attract investors. } \\
\text { Under increased investment promotion the region } \\
\text { can turn into or «star» (for «applicants»), or go to } \\
\text { the group «cash cows» (for «question marks»). }\end{array}$ \\
\hline $\begin{array}{c}\text { Low investment } \\
\text { potential } \\
\text { (IP assessment }= \\
\{4 ; 5 ; 6\})\end{array}$ & $\begin{array}{c}\text { „Cash cows” } \\
\text { Crimea, Transcarpathian, Kyiv, Odessa } \\
\text { oblasts } \\
\text { (region receives more FDI than could } \\
\text { potentially expect) } \\
\text { Strategy - maintaining. Strengthening of } \\
\text { the current sources of investments. Exces- } \\
\text { sive FDI inwards can give better results if } \\
\text { to share it with the «question marks». }\end{array}$ & $\begin{array}{c}\text { „Outsiders" } \\
\text { (hopeless) } \\
17 \text { regions, particularly } \\
\text { Ternopol, Kherson, Khmelnitsky oblasts } \\
\text { Strategy - regions require more attention and ef- } \\
\text { forts of local and state governments to attract even } \\
\text { small FDI flows; shift to domestic investments (e.g. } \\
\text { by «stars»). }\end{array}$ \\
\hline
\end{tabular}

Source: author's calculations

For the strategic analysis it is also feasible to build DPM (General Electric) matrix - Matrix "investment attractiveness - Investment Activity (IA)" (Table 8) according to the "principle of traffic light".

Matrix «investment attractiveness - Investment Activity (IA)»

\begin{tabular}{|c|c|c|c|}
\hline \multirow{2}{*}{$\begin{array}{c}\text { Investment at- } \\
\text { tractiveness }\end{array}$} & \multicolumn{3}{|c|}{ Investment activity } \\
\hline & High & Average & Low \\
\hline High & $\begin{array}{c}1 \\
\text { Kyiv }\end{array}$ & 2 & 3 \\
\hline Average & $\begin{array}{l}4 \\
\text { Dnipropetrovs' } k \\
\text { region }\end{array}$ & $\begin{array}{c}5 \\
\text { Transcarpathian, Donetsk, Zapor- } \\
\text { izhzhya, Kyiv, Kharkiv, Odessa, Lviv, } \\
\text { Poltava regions, Crimea. }\end{array}$ & $\begin{array}{c}6 \\
\text { Mykolaiv, Volyn, Rivne, Sumy, Cherkasy, } \\
\text { Ivano-Frankivsk, Chernivtsi, Vinnitsa, } \\
\text { Kirovograd, Chernihiv, Luhansk, Zhytomyr } \\
\text { regions. }\end{array}$ \\
\hline Low & 7 & 8 & $\begin{array}{c}9 \\
\text { Ternopol, Kherson, Khmelnitsky oblasts }\end{array}$ \\
\hline
\end{tabular}

Source: author's calculations

In Table 8:

1, 2, 4 - "green zone " - a zone of good prospects in terms of production and business potential for further investment and growth,

Strategy - enhancing of foreign direct investment inwards in the region;

3, 5, 7 - "yellow zone" - a zone of moderate prospects,

Selective investment strategies for a particular zone: 
zone \#3 - extensive invest -promotion of the region should be carried out to consolidate the position of "leader";

zone \#5 - the investment strategies of the "main massive" positions solidifying should be implemented; zone \# 7 - it is necessary to strategically use the investors' interest for increasing the attractiveness of the region for further conversion into the zone \#4;

6, 8, 9 - "red zone" - a non-perspective zone due to the overall low investment attractiveness and weak investment activity,

- Selective investment strategies according to a particular zone:

zone \#6 and \#8 - strategy "to collect the harvest";

zone \#9 - it is better for the region for some time to focus on domestic sources of investments and "neighbor effects" of regions that are in the "green zone".

An investment promotion of regions should be supported by the following immediate measures of promoting of investment opportunities at the regional level of the country to interest potential investors:

- Development of regional passports and "Investment Guide";

- Establishment of regional centers of project financing for preparing business plans according to international standards (standards recommended by UNIDO and practiced by leading global firms).

\section{CONCLUSION \& DISCUSSION}

The phenomenon of investment attractiveness is still a challenge for development of unified flexible/ easy-adaptive, operative and adequate technique of its assessment because of its nature that is highly fragile for external changes and shocks. Investment opportunities and potential of Ukrainian regions that are analyzed in the paper show the ability to implement the economic-mathematical method to rank regions according to their level of investment potential, the degree of investment risks, the experience of previous investment activity in the region, with further marketing approach aimed to propose investment strategies for every particular region/group of regions to attract maximum efficient volume of investing. The research results can be potentially interested and useful for potential investors, governors, investment advisers and analytics. The novelty of this paper mostly is about the proposed so-called territorial investment marketing, based on the results of a comprehensive monitoring of the regional investment climate of Ukraine.

A comparative analysis of regional investment opportunities in the efficiency profile that was held highlighted the regions-leaders - Kyiv and Dnipropetrovs'k region - as the most attractive from the investment point of view. While infrastructure is undoubtedly a key factor, the concentration of industry, the scale and educational levels of the labour force are as well main factors that enhanced this result for the regions. According the official statistics Kyiv and Dnipropetrovs'k region count the highest amount of enterprises in Ukraine that is the litmus of the economic maturity of the regions itself (75338 and 27363 in 2012, correspondently). As well, if to compare the operating profitability of enterprises, it is the highest over Ukraine for these two regions (more than 5\% in average, that is higher that Ukrainian average). If to follow the experts' opinion, as the head of Dnipropetrovs'k region has noticed (http://www.dia.dp.ua/en/ news/648/): the creation of image of Dnipropetrovs'k region as a reliable business partner is conducted successfully because of Dnipropetrovs'k Investment Agency (DIA) operating in the region. This factor of "government openness" is widely considered as the main factor of the success for observed regions (Rating of investment attractiveness of regions 2013, Project IFC «Investment climate in Ukraine”) The location effects of foreign investors in these two oblasts are also a useful attractiveness indicator: thus, Germany 
$(51,1 \%)$, Cyprus $(29,2 \%)$ are main investors in Dnipropetrovs'k region on the date $01 / 12 / 13$. As to Kyiv - Cyprus (about 32\%) is a main investor.

The research provide the evidence that marketing positioning should be based on the results of monitoring of investment attractiveness followed by selective strategies for different groups of investors and different groups of potential investment targets. Ranking of regions according key groups of factors - components of investment attractiveness - will update the directions of a comprehensive investment program to increase the investment attractiveness of a particular region, determine its orientation and perspective possible efficiency, determine national priorities. For motivation of foreign investors to invest in Ukraine under current geo-political situation very significant changes are required in the investment climate. It is necessary to maintain radical measures to develop a clear government strategy of investment attraction. In general, the following group of investment priorities can be proposed (based on the information from Table 7-8): financial ("tactical"), that promise rapid payback and the accumulation of resources for further investment; innovative ("strategic"), that create new industries and markets, that in its turn will alter the structure of the economy; social and infrastructure, that affect the level of welfare, labor mobility and the development of industries in general.

\section{REFERENCES}

Analytical agency "Dragon-Capital", http://www.dragon-capital.com.

Ansoff, I. (1989), Strategic Management, Moscow: Economy.

Bandurka, A.A., Bandurka, A.M., Nosova, O.V. (2004), Foreign investments in the Ukrainian economy, Kharkiv: Publisher of National Univ. of Internal Affairs.

Cabinet of Ministers of Ukraine, http://www.kmu.gov.ua.

Dnipropetrovsk region and Kyiv city are the most attractive to the foreign investors, http://www.dia.dp.ua/en/news/648/

„Expert-RA and AK\&M" Agency, http://www.akm.ru.

Inozemni investytsii v Ukraini (2004), K.: Redaktsiino-vydavnyche viddilennia UkrINTEI.

Institute of Reforms, http://www.ipa.net.ua.

Kanaschenko, O.L. (2004), Mizhnarodny Marketing: teoriya i gospodarski situatsii, Kyiv: IVTS "Politehnika".

Kharlamova, G.O. (2003), Formuvannia investytsiinoho potentsialu transformatsiinoi ekonomiky Ukrainy, Aktualni problemy rozvytku pidpryiemnytskoi diialnosti v Ukraini, K.: Vydavnycho-polihrafichnyi tsentr „Kyivskyi universytet", Vol. 3, pp. 132-143.

Kharlamova, G.O. (2006), Ekonomiko-filosofskyi kontekst priamoho inozemnoho investuvannia: zahalne, osoblyve, odynychne, Praktychna filosofia, Vol. 3 (21), pp. 128-138.

Kharlamova, G. (2007), Modeliuvannia vplyvu rehionalnoho faktoru na nadkhodzhennia priamykh inozemnykh investytsii v Ukraini, Ekonomist, Vol. 5, pp. 50-53.

Kharlamova, G. (2008), Attraction evaluation of objects for investment, Actual Problems of Economics, Vol. 9, pp. 73-79.

Kharlamova, G. (2013), The investment component of economic security: the case of Ukraine. In: Borys, M., Kharlamova, G. (Eds.), Ukrainian Economics Actual Research Problems in Eastern Europe, Lublin: Politechnika Lubelska, pp. 21-34.

Kotler, O.F. (1995), Osnovy marketynha. Moscow: Byznes-knyha.

Kovaliov, A.I., Voylenko, V.V. (2000), Marketing analysis, Moscow: Library economic leader.

National Bank of Ukraine, http://www.bank.gov.ua.

Nosova,O.V. (2001), Inostrannie investitsii v tranzitivnoi ekonomike Ukrainy, Kharkiv: Osnova. 
Project IFC «Investment climate in Ukraine", http://ifc.org/ukraine/ic

Rating of investment attractiveness of regions 2013, hppt://www.ukrproject.gov.ua

Rogach, O.I. (2005), Mizhnarodni investytsii: Teoriia ta praktyka biznesu transnatsionalnykh korporatsii, Kiev: Lybid.

Soldatenko, V.V., Fedorenko, S.V. (2005), Monitorynh investytsiinykh mozhlyvostei priamykh inozemnykh investoriv v Ukrainy, Investytsii: praktyka ta dosvid, Vol. 10, pp. 22-30.

Soshnikova, L.A., Tamashevich, V.N., Uebe G., Schaeffer, M. (1999), Multivariate Statistical Analysis in Economics, Moscow: UNITY.

State Statistics Service of Ukraine, http://www.ukrstat.gov.ua 